\title{
ZNACZENIE REGULACJI RYNKU DORADZTWA FINANSOWEGO ORAZ POŚREDNICTWA FINANSOWEGO W KONTEKŚCIE OCHRONY KONSUMENTA I WSPIERANIA BEZPIECZEŃSTWA SYSTEMU FINANSOWEGO
}

\begin{abstract}
Streszczenie
Celem artykułu jest synteza istniejacych na rynku regulacji i rekomendacji w zakresie doradztwa i pośrednictwa finansowego oraz analiza znaczenia tych instytucji dla sektora finansowego. W artykule postawiono hipotezę, że rynek doradztwa finansowego i pośrednictwa finansowego nie jest wystarczająco prawnie uregulowany, co jest istotne w zwiazku ze wzrostem znaczenia tego rynku. Przedstawione w pracy instytucje oraz ich regulacje rynku doradztwa finansowego, będące obiektem badań w niniejszym artykule, wskazują że istotna działalność doradców finansowych nie jest dostatecznie uregulowaną dziedziną. Niebankowe instytucje finansowe (NBIF) mają coraz większy wpływ na stabilność sektora bankowego i tym samym systemu finansowego, a w zwiazku z tym, że prowadzą coraz szerszą działalność finansową ważna pozostaje kwestia regulacji tych instytucji. Ponadto, równowaga w sektorze finansowym powinna opierać się na odpowiednio uregulowanym rynku finansowym. Wobec wzrostu znaczenia rynku doradztwa i pośrednictwa finansowego ważna staje się kwestia regulacji szczególnie dotycząca rynku doradztwa finansowego, która nie jest jeszcze wystarczająco doprecyzowana, co stanowi postawioną w artykule hipotezę badawcza.
\end{abstract}

Słowa kluczowe: doradztwo finansowe, pośrednictwo finansowe, sektor bankowy

\section{IMPORTANCE OF REGULATING FINANCIAL CONSULTANCY AND FINANCIAL INTERMEDIATION MARKET: CONSUMER PROTECTION AND SUPPORTING FINANCIAL SYSTEM SECURITY}

\section{Summary}

The purpose of this paper is to provide a synthesis of the existing market regulations regarding the financial consultancy and financial intermediation markets, and to conduct an analysis of the importance of these institutions for the financial sector. The conclusion is that the markets in question are not sufficiently regulated, which is important in view of their increasing importance. Furthermore, the balance of the financial sector should be based on a properly regulated financial market. However, the issue of regulations of the financial consultancy market has not been yet sufficiently addressed.

Key words: financial consultancy, financial intermediation, banking sector

\footnotetext{
${ }^{1}$ Dr Joanna Stawska - Wydział Ekonomiczno-Socjologiczny, Uniwersytet Lódzki; e-mail: joanna.stawska@, uni.lodz.pl.
} 


\section{Wstęp}

Doradztwo oraz pośrednictwo finansowe są nieodłączną częścią rynku finansowego i należą do usług finansowych. Według M. Iwanicz-Drozdowskiej, przez pojęcie usługi bądź produktu finansowego rozumie się usługę, którą świadczy podmiot funkcjonujący w sektorze usług finansowych (pośrednik finansowy), związaną z inwestowaniem lub pozyskiwaniem środków pieniężnych oraz zapewnieniem odpowiedniego przepływu środków między uczestnikami rynku. Tym produktem lub usługa finansową mogą być, np.: depozyt, kredyt, umowa ubezpieczeniowa, jednostka funduszu inwestycyjnego, polecenie przelewu lub produkt zintegrowany [Iwanicz-Drozdowska, 2009, s. 10]. Według J.F. Sinkeya, sektor usług finansowych (financial service industry) jest złożony z firm świadczacych usługi finansowe (financial services firms), [Sinkey, 1998, s. 5]. Firmy te nazywa się tradycyjnie pośrednikami finansowymi i są to: banki, spółdzielnie kredytowe, zakłady ubezpieczeń, fundusze inwestycyjne, fundusze emerytalne, fundusze hedingowe, firmy venture capital, pośrednicy kredytowi oraz agencje finansowe. Istnieje możliwość sprzedaży danej usługi finansowej zarówno przez podmiot tworzący dany produkt (np. firma zarządzająca funduszem inwestycyjnym), jak i instytucję, która pośredniczy w zawieraniu transakcji (np. firma doradztwa finansowego), [Iwanicz-Drozdowska, 2009, s. 10]. Firma doradztwa finansowego to instytucja zajmująca się usługą pośrednictwa i doradztwa przy zakupie produktów: lokacyjnych, oszczędnościowych, inwestycyjnych, ubezpieczeniowych i innych, doradzając jednocześnie klientowi w wyborze struktury aktywów. Doradztwo finansowe obejmuje pomoc klientowi w wyborze najlepszej dla niego oferty dostępnej na rynku w zakresie potrzeb klienta i jego możliwości finansowych. Doradztwo finansowe jest oparte na długofalowych relacjach z klientami. Dzialania doradców dotyczą: oceny sytuacji finansowej, pomocy w podjęciu decyzji finansowych, dopasowania oferty do indywidualnych potrzeb klienta $i$ innych usług ułatwiających aktywne zarządzanie własnymi finansami [Waliszewski, 2010, s. 200]. W kontekście ochrony interesu klienta oraz działań na rzecz troski o bezpieczeństwo finansowe klienta doradca finansowy świadczy klientowi usługi na jak najwyższym poziomie. Ponadto, doradca powinien być niezależny i zobowiązany do udzielania bezstronnych porad, pobierając wynagrodzenie wyłącznie od swojego klienta. Zadaniem doradcy finansowego jest informowanie i uświadamianie klienta o jego prawach wynikających z przepisów w zakresie ochrony konsumenta usług finansowych [Waliszewski, 2014, s. 212].

Pośrednik kredytowy to firma, która pośredniczy między bankiem a klientem w celu ustalenia warunków transakcji i podpisania umowy kredytowej. Instytucja taka może współpracować z jednym bankiem lub wieloma, wtedy w tym drugim przypadku można mówić o brokerach kredytowych. W rezultacie pośrednictwo finansowe wiąże się z działalnością instytucji polegająca na równoważeniu popytu na środki finansowe przez podmioty deficytowe $\mathrm{z}$ ich podażą podmiotów nadwyżkowych [Waliszewski, 2010, s. 201].

Coraz więcej banków decyduje się na zwiększanie oferty kredytowej dla klientów poprzez placówki własne oraz współpracujące z nimi na podstawie umowy agencyjnej czy franczyzy oddziały zewnętrzne lub dzięki współpracy z pośrednikami kredytowymi czy 
finansowymi. W związku z tym, na produkty oferowane na rynku consumer finance występuje znaczny popyt, a sam rynek stał się obszarem narastającej konkurencji. Jest to rynek, na którym usługi kredytowe i doradztwo w obszarze inwestowania czy sprzedaży produktów inwestycyjnych jest świadczone przez: banki, przedsiębiorstwa pośrednictwa kredytowego, firmy pożyczkowe i niezależnych doradców na rzecz klientów indywidualnych [Waliszewski, 2010, s. 197 - 201].

Bitz przedstawił sposób oddziaływania pośredników finansowych na efektywność tworzenia równowagi pomiędzy popytem a podaża środków finansowych. W tym celu wyróżnił podstawowe przeszkody pojawiające się na rynkach finansowych funkcjonujących bez pośredników finansowych. Są to następujące problemy informacyjne:

- niedostosowania popytu do podaży środków finansowych;

- $\quad$ czasowej struktury popytu i podaży środków finansowych oraz ryzyka [Bitz, 1996, s. 30-31].

Istnienie pośredników finansowych rozwiązuje powyższe problemy. W literaturze jest to nazywane efektem transformacji [Bitz, 1996, s. 30- 35].

W tym miejscu należy podkreślić, że w Polsce brak jest prawnych regulacji rynku doradztwa finansowego oraz obowiązku certyfikacji i licencjonowania doradców finansowych, ponadto rynek ten nie jest dodatkowo objęty nadzorem instytucjonalnym [Waliszewski, 2012, s. 481].

Celem artykułu jest synteza istniejących na rynku regulacji i rekomendacji w zakresie doradztwa i pośrednictwa finansowego oraz analiza znaczenia tych instytucji dla funkcjonowania sektora finansowego. W artykule postawiono hipotezę, że rynek doradztwa finansowego i pośrednictwa finansowego nie jest wystarczająco prawnie uregulowany, co jest istotne w związku ze wzrostem znaczenia tego rynku. W celu zweryfikowania postawionej hipotezy wykorzystano następujące metody badawcze: przegląd literatury naukowej oraz metody graficznej prezentacji zjawisk gospodarczych. Wprowadzenie regulacji doradztwa i pośrednictwa finansowego powinno przyczynić się do zwiększenia ochrony interesu konsumentów, a w konsekwencji pozytywnie wpłynąć na bezpieczeństwo i stabilność systemu finansowego.

\section{Instytucje rynku pośrednictwa oraz doradztwa finansowego na tle regulacji rynku usług finansowych}

Pojęcia usługi finansowe oraz sektor usług finansowych pojawiły się po raz pierwszy w Stanach Zjednoczonych. W Europie natomiast przełomowym momentem było opublikowanie i przyjęcie przez Komisję Europejską w 1999 roku dokumentu pt.: Plan driatan w zakeresie ustug (Financial Services Action Plan - FS AP). W 2000 roku FS AP został włączony do Strategii Lizbońskiej, co zwiększyło jego znaczenie jako programu, który miał zmienić oblicze europejskiej gospodarki. Komisja Europejska opublikowała również, jako kontynuacje programu FS AP, tzw. Zieloną Księgę (Green Paper on Financial Services Policy), w której zawarto propozycje działań dotyczących budowy jednolitego rynku finansowego na następnym etapie, w latach 2005-2010. Zielona Księga poprzedziła opublikowanie tzw. Białej Księgi (White Paper on Financial Services Policy), w której osta- 
tecznie sformułowano strategię Unii Europejskiej wobec sektora usług finansowych [Janicka, 2005, s. 42]. Istotny jest fakt, że instytucje oferujące usługi finansowe dzielą się na takie, które częściowo podlegają regulacjom nadzorczym (banki, zakłady ubezpieczeń, firmy inwestycyjne) oraz na takie, które nie podlegają tym regulacjom (fundusze hedgingowe, agencje finansowe). Generalnie, te instytucje, które tworzą usługi finansowe, objęte są regulacjami nadzorczymi (oprócz funduszy hedgingowych), natomiast sprzedażą tych usług zajmują się podmioty objęte, jak również nieobjęte nadzorem.

Warto w tym miejscu zauważyć, że od kwietnia 2010 roku w Polsce istnieje obowiązek przestrzegania unijnej Dyrektywy MiFID (Markets in Financial Instruments Directive, 2004/39/EC²) dotyczącej rynków instrumentów finansowych, która z założenia ma chronić klientów m.in.: towarzystw funduszy inwestycyjnych, banków, domów maklerskich oraz pośredników finansowych. Zgodnie z zaleceniami Dyrektymy MiFID, instytucje finansowe podczas sprzedaży swoich produktów mają obowiązek rzetelnego informowania klientów o ryzyku. Według MiFID, podmioty, które oferują usługi inwestycyjne, zobowiązane są działać w sposób: uczciwy, rzetelny i profesjonalny, zgodnie z najlepiej pojętymi interesami klientów. Informacje wiążące się z instrumentami finansowymi przekazywane klientom powinny być: zrozumiałe, przejrzyste i przede wszystkim dostosowane do profilu klienta, a także powinny obejmować dane o ryzyku związanym z danym instrumentem [www.bgk.com.pl]. W 2014 roku wprowadzono nowa dyrektywę MiFID II (Dyrektywa 2014/17/UE), która reguluje chociażby kwestie wynagradzania za usługi doradztwa finansowego (w celu ograniczenia sugerowania klientom produktów o wysokich prowizjach dla doradców), ponadto zwiększa stabilność i przejrzystość rynku finansowego oraz wprowadza ankietowanie klienta pod kątem konstrukcji produktu i ryzyka [www.kpf.pl]. Szczególnie współcześnie wyżej wspomniana dyrektywa nabiera większego znaczenia, kiedy na rynku pojawia się coraz więcej skomplikowanych usług oferowanych przez różne podmioty.

Warto dodać, że w 2014 roku na szczeblu unijnym weszła w życie tzw. dyrektywa hipoteczna, która w Polsce ma zostać zaimplementowana w 2016 roku. Głównym założeniem tej dyrektywy jest lepsza ochrona praw konsumenta, co ma nastapić poprzez zmiany na rynku pośrednictwa finansowego ( $w$ tym m.in. zmiany systemu wynagradzania doradców finansowych - gdzie system prowizji może zostać zastąpiony przez honoraria oraz pewne regulacje i nadzór nad pośrednikami i doradcami kredytów hipotecznych).

Oprócz funduszy inwestycyjnych, kredytów czy ubezpieczeń, firmy doradztwa finansowego oferują również złożone usługi, takie jak chociażby produkty strukturyzowane. Może to wynikać z ogólnej dostępności zawodu doradcy finansowego, który nie jest regulowany żadnymi przepisami, a oferta i jakość świadczonych przez doradcę usług zależy od firmy, dla której pracuje lub zależy tylko od doradcy, który prowadzi jednoosobową działalność gospodarczą. Na rynku funkcjonuje bardzo dużo firm

${ }^{2}$ Dyrektywę MiFID tworzą następujące akty prawne: Dyrektywa 2004/39/WE Parlamentu Europejskiego $i$ Rady z 21 kwietnia 2004 roku w sprawie rynków instrumentów finansonych oraz Dyrektywa nr 2006/31/WE Parlamentu Europejskiego $i$ Rady z dnia 5 kwietnia 2006 roku, która zmienia Dyrektywe 2004/39/WE w sprawie niektórych terminów, a także Dyrektywa Komisji 2006/73/WE z 10 sierpnia 2006 roku, która jest aktem wykonawczym do Dyrektyny 2004/39/WE. 
świadczących usługi doradztwa finansowego, co jest konsekwencją rozproszenia tego rynku oraz różnego interpretowania zawodu doradcy finansowego. Stąd w celu pewnej systematyzacji należy zwrócić uwagę na działalność organizacji zrzeszających doradców finansowych [http://www.bankier.pl/static/att/90000/2492942_RaportRynek Doradztwa FinansowegowPolsce2012.pdf].

$\mathrm{Na}$ polskim rynku istnieje m.in. Zwiazek Firm Doradztwa Finansowego [Ustawa z dnia 23 maja..., 1991], który powstał w 2008 roku i skupia firmy zajmujące się doradztwem i pośrednictwem finansowym. Należą do niego największe firmy doradztwa w Polsce, tj.: Aspiro, Bankier, Doradcy 24, Expander, Gold Finance, Home Broker, Open Finance, Idea Expert, Notus Doradcy Finansowi, FinPack. Ze względu na dobro i potrzeby klienta, zawód doradcy powinien stać się zawodem godnym zaufania publicznego, dlatego ZFDF wypracował wspólny standard pracy doradców finansowych. Podjęto również uchwałę o działaniu według Kanonu Dobrych Praktyk Rynku Finansowego, który uzyskał rekomendację Komisji Nadzoru Finansowego (KNF), podkreślając tym samym wagę regulacji i ograniczeń, jakie uczestnicy rynku finansowego dobrowolnie nakładaja na siebie, $\mathrm{z}$ uwzględnieniem mediacji, która umożliwia realizację różnych interesów stron umów zawieranych na rynku finansowym. W 2008 roku KNF zatwierdziła Uchwate nr 99/08 w sprawie rekomendacji stosowania Kanonu Dobrych Praktyk Rynku Finansowego, jednocześnie przyjmując rezultat prac instytucji i organizacji rynku finansowego nad Kanonem [Uchwała nr 99/08..., 2008]. Przypisano w nim duże znaczenie zarówno standardom etycznym, jak i jakościowym z naciskiem na opracowywanie i wdrażanie wspólnego standardu raportowania wyników sprzedażowych, jak również stworzenie kompendium wiedzy niezbędnej klientowi w momencie podejmowania decyzji finansowych [Statut Zwiazku Firm Doradztwa Finansowego, 2008]. Komisja Nadzoru Finansowego oparła powyższe uchwały na art. 11 ust. 1 Ustany z dnia 21 lipca 2006 roku o nadzorze nad rynkiem finansonym (Dz. U. Nr 157, poz. 1119 z późn. zm.). Kanon Dobrych Praktyk Rynku Finansowego ma zapewnić zrównoważony rozwój i bezpieczeństwo rynku, którego podstawa jest etyczny wymiar działań podmiotów finansowych. Kanon wskazuje zasadnicze wartości i ideały etyczne, którymi powinny kierować się podmioty finansowe, a przy zachowaniu tajemnicy zawodowej i handlowej powinny współdziałać w promowaniu dobrych praktyk rynkowych i ładu korporacyjnego [Kanon Dobrych Prakty) Rynku Finansowego]. Istotna inicjatywa jest przyjęcie w 2014 roku przez Związek Firm Doradztwa Finansowego i Związek Banków Polskich „Rekomendacji dobrych praktyk dla Doradców kredytowych. Kredyty hipoteczne" co stanowi ważny krok w kierunku usystematyzowania zasad stosowanych przez doradców kredytowych.

Od 2002 roku działa również Polska Izba Pośredników Ubezpieczeniowych i Finansowych (PIPUiF), która funkcjonuje na podstawie przepisów Ustany z. dnia 30 maja 1989 roku o ižbach gospodarczych (Dz.U. Nr 35, poz. 195 ze zm.). Izba jako organizacja samorządu gospodarczego zrzeszająca instytucje gospodarcze współpracuje z ponad 12 tys. pośredników ubezpieczeniowych i finansowych. Ponadto, od 2003 roku Polska Izba Pośredników Ubezpieczeniowych i Finansowych została członkiem Europejskiej Federacji Pośredników Ubezpieczeniowych (BIPAR), która powstała w 1937 roku. Europejska Federacja Pośredników Ubezpieczeniowych ma siedzibę w Brukseli 
i zrzesza 50 organizacji krajowych, które reprezentuja ponad 250 tys. pośredników ubezpieczeniowych. Do istotnych osiagnięć BIPAR należy założenie i bycie członkiem Światowej Federacji Pośredników Ubezpieczeniowych (World Federation of Insurance Intermediaries - WFII), [http://www.bipar.eu/], która zrzesza 100 organizacji z 80 krajów świata. Europejska Federacja Pośredników Ubezpieczeniowych jest uznawana przez Komisję Europejską a Światowa Federacja Pośredników Ubezpieczeniowych przez: OECD, WTO czy IAIS [http://www.posrednicy.org.pl/statut]. Celem PIPUiF jest: uczestnictwo w tworzeniu aktów prawnych związanych z działalnością ubezpieczeniową i finansowa, reprezentowanie interesów środowiska, a także współpraca z instytucjami i organizacjami rynku finansowego i ubezpieczeniowego. Poza tym, do zadań Izby należy: zwiększanie świadomości ubezpieczeniowej i finansowej w społeczeństwie, podnoszenie kwalifikacji zawodowych pośredników oraz etyki zawodowej. Polska Izba Pośredników Ubezpieczeniowych i Finansowych również kieruje się zasadami Kodeksu Etyki [http://www.posrednicy.org.pl/ kodeks-etyki].

Doradcy finansowi mają możliwość uzyskania certyfikatów o trzech stopniach zaawansowania honorowanych na terenie Unii Europejskiej i wydawanych przez Europejską Akademię Planowania Finansowego. Europejska Akademia Planowania Finansowego wywodzi się z Europäische Akademie für Finanzplanung (European Academy of Financial Planning - EAFP) powstałej w Bad Homburgu. W grudniu w 2003 roku EAFP z siedziba w Bad Homburgu podpisała porozumienie o utworzeniu w Polsce Europejskiej Akademii Planowania Finansowego. Akademia funkcjonuje na podstawie wzorów edukacyjnych oraz systemu certyfikacji, który potwierdza zdobyte kwalifikacje niezbędne do świadczenia usług w zakresie doradztwa finansowego na terenie krajów Unii Europejskiej. Umożliwia zdobycie certyfikatów honorowanych na terenie Unii Europejskiej, takich jak: European Financial Guide - EFG (Asystent Finansowy - Pośrednik Finansowy), European Financial Consultant - EFC (Doradca Finansowy), European Financial Planner - EFP (Planer Finansowy), [http://www.eafp.pl/ index.php?menuid $=14]$.

W 2006 roku powołano w Warszawie Europejską Federację Doradców Finansowych Polska - EFFP Polska (European Federation of Financial Professionals - EFFP). Stowarzyszenie to powstało jako organizacja partnerska niemieckiej EFFP z siedzibą w Bad Homburgu, która wydaje certyfikaty EFFP na trzech poziomach. Co więcej, EFFP Polska posiada osobowość prawną jak również jest organizacją akredytowaną i zrzeszoną w ramach Europejskiej Federacji Doradców i Pośredników Finansowych - FECIF (The European Federation of Financial Advisers and Financial Intermediaries), [http://www.fecif.eu/], będąc jednocześnie przedstawicielem FECIF na terenie Polski. Europejska Federacja Doradców i Pośredników Finansowych została założona w 1999 roku z siedziba w Brukseli i jest najstarszą organizacja powstała w celu ochrony oraz promocji roli pośredników i doradców finansowych w Europie [http://www.effp.pl/]. Absolwenci kolejnych stopni Europejskiej Akademii Planowania Finansowego otrzymuja certyfikaty EFFP, niezależnej instytucji certyfikującej doradców finansowych. Osoba posiadająca wyżej wymienione certyfikaty, będąc członkiem EFFP, zobowiązana jest przestrzegać "Zasad Etycznych EFFP” [http://www.effp.pl/page/2.html]. Dodatkowo, dwustopniowe egzaminy na dorad- 
ców finansowych według standardów EFPA (European Financial Planning Association) przeprowadza Fundacja na rzecz Standardów Doradztwa Finansowego powołana przez Warszawski Instytut Bankowości. Wobec braku regulacji rynku doradców finansowych certyfikacja doradców finansowych podnosi jakość świadczonych usług dzięki pewnej standaryzacji ich świadczeń, a za sprawą zapewnienia przestrzegania norm etycznych przez certyfikowanych doradców stanowi formę tzw. samoregulacji i tym samym zwiększa poziom zaufania do zawodu [Waliszewski, 2012, s. 488; Waliszewski, 2014, s. 216].

W tym miejscu warto podkreślić, że to właśnie stowarzyszenie EFFP Polska przy współpracy z Ministrem Pracy i Polityki Społecznej podjęło się próby uznania zawodu doradcy finansowego. Na podstawie Ustany z. dnia 20 kwietnia 2004 roku art. 36 ust. 8 o promocï zatrudnienia i instytucjach rynku pracy opracowano „Listę Klasyfikacji Zawodów i Specjalności" [http://stat.gov.pl/ Klasyfikacje/doc/kzs/pdf/KZiS_nowa.pdf] w formie Rozporzadzenia Ministra Pracy i Polityki Społecznej w sprawie klasyfikacji zawodów i specjalności na potrzeby rynku pracy i polityki spotecznej oraz zakresu jej sto sowania. Stowarzyszenie EFFP w ramach czynnych prac przygotowawczych do nowych i uaktualnianych przepisów prawnych wysunęło sugestie i rekomendacje, które zostały zawarte w „Uzasadnieniu do Projektu Rozporządzenia Listy Klasyfikacji i Standaryzacji Zawodów" [http://www.mpips.gov.pl/bip/]. W rezultacie z dniem 1 lipca 2010 roku weszło w życie Rosporzadzenie Ministra Pracy i Polityki Spotecznej w sprawie klasyfikacji zanodów i specjalności na potrzeby rynku pracy i polityki spotecznej oraz zakresu jej stosowania [Rozporzqdrenie, 2010, art. 36] z zapisem o umieszczeniu doradcy finansowego w grupie zawodowej o numerze 2412, zwanej „Doradcy finansowi i inwestycyjni”. Podobnie pośrednik finansowy został wpisany na „Listę Klasyfikacji i Standaryzacji Zawodów” w grupie zawodowej o numerze 3311. Dodatkowo, 15 października 2013 roku zatwierdzono Krajowy Standard Kompetencji Zawodowych dla zawodu doradcy finansowego, jednocześnie określając, kto może wykonywać ten zawód i jakie powinien mieć kwalifikacje kandydat do pracy w zawodzie doradcy finansowego [Rozporzadzenie Ministra Pracy..., 2010, Dz. U. Nr 82, poz. 537].

Podsumowując temat instytucji zrzeszających doradców finansowych na tle regulacji rynku usług finansowych, należy wspomnieć, że wśród podmiotów działających na rynku usług finansowych istotna rolę odgrywają konglomeraty finansowe oraz grupy kapitałowe, co jest wynikiem tendencji integracyjnych. Konglomeraty w swoich strukturach mogą zawierać podmioty jednolicie regulowane na szczeblu unijnym, czyli banki, zakłady ubezpieczeń, firmy inwestycyjne oraz fundusze inwestycyjne, tak jak: UCITS (Undertakings for the Collective Investment in Transferable Securities) $)^{3}$ i nieregulowane w sposób jednolity, tj.: pośrednicy kredytowi, doradcy finansowi, niektóre fundusze inwestycyjne zamknięte, fundusze hedgingowe, agencje finansowe czy instytucje mikrofinansowania. Wyżej opisani pośrednicy działający w ramach konglomeratu podlegają pewnego rodzaju regulacjom mającym charakter samorządowy i dotyczaç sposobu prowadzenia biznesu. W Europie tego typu uregulowań dokonuje European Federation of

\footnotetext{
${ }^{3}$ UCITS to przedsiębiorstwa zbiorowego inwestowania w zbywalne papiery wartościowe.
} 
Finance House Associations, skupiająca stowarzyszenia pośredników kredytowych z takich krajów, jak: Belgia, Czechy, Finlandia, Francja, Hiszpania, Holandia, Irlandia, Niemcy, Norwegia, Polska (od stycznia 2006 roku), Portugalia, Szwecja, Wielka Brytania i Włochy [http://jobs.euractiv.com/company/eurofinas-european-federation-financehouse-associations-10428].

$\mathrm{Na}$ szczeblu europejskim istnieje również organizacja European Financial Planning Association (EFPA), w skład której wchodzą organizacje doradców finansowych z: Belgii, Cypru, Danii, Hiszpanii, Holandii, Irlandii, Niemiec, Wielkiej Brytanii i Włoch. Stowarzyszenie to ma charakter samorządowy, czyli działa na zasadzie samoregulacji niezależnej grupy pośredników finansowych i chroni klientów głównie w kwestiach etycznych prowadzenia biznesu czy kompetencji zawodowych. Szczególnie niezbędne jest istnienie tego typu stowarzyszeń, chociażby ze względu na to, że doradcy finansowi nie ponoszą ryzyka, dokonując tylko sprzedaży produktów stworzonych przez inne podmioty. Ponadto, niezależni doradcy finansowi wykorzystują otwartą architekturę finansową (open product arcbitecture), czyli oferują usługi i produkty wielu różnych dostawców [www.efpa-europe.org].

\section{Funkcjonowanie rynku doradztwa i pośrednictwa finansowego w Polsce}

Poniżej zostały przedstawione dane statystyczne obejmujące działalność firm doradztwa finansowego oraz pośrednictwa kredytowego w latach 2007-2013. Przede wszystkim skupiono uwagę na firmach pośrednictwa kredytowego, czyli podmiotach, które działają na rzecz banków, pośrednicząc pomiędzy bankiem a kredytobiorca. Należy pamiętać, że pośrednik finansowy jest pojęciem znacznie szerszym od pośrednika kredytowego. Zaprezentowane dane dotyczą m.in.: zakresu działalności pośredników, ilości zatrudnianych przez nich pracowników, liczby umów i wartości udzielonych przez nie kredytów i pożyczek, jak również struktury sprzedanych produktów.

TABELA 1.

Zakres działalności przedsiębiorstw pośrednictwa kredytowego w Polsce, w latach 2007-2013

\begin{tabular}{|l|c|c|c|c|c|c|c|}
\hline \multirow{2}{*}{$\begin{array}{l}\text { Zakres działalności } \\
\text { firm pośrednictwa } \\
\text { kredytowego }\end{array}$} & \multicolumn{7}{|c|}{ Ilość firm w poszczególnych latach } \\
\cline { 2 - 9 } & $\mathbf{2 0 0 7}$ & $\mathbf{2 0 0 8}$ & $\mathbf{2 0 0 9}$ & $\mathbf{2 0 1 0}$ & $\mathbf{2 0 1 1}$ & $\mathbf{2 0 1 2}$ & $\mathbf{2 0 1 3}$ \\
\hline $\begin{array}{l}\text { Pośrednictwo w udzie- } \\
\text { laniu kredytów od ban- } \\
\text { ków }\end{array}$ & 29 & 39 & 43 & 44 & 45 & 43 & 64 \\
\hline $\begin{array}{l}\text { Wyłącznie pożyczki } \\
\text { z własnych środków }\end{array}$ & 4 & 8 & 13 & 15 & 16 & 22 & 50 \\
\hline $\begin{array}{l}\text { Prowadzenie działalnoś- } \\
\text { ci mieszanej }\end{array}$ & - & - & - & - & 3 & 4 & 4 \\
\hline
\end{tabular}

Źródło: dane GUS: [D viatalnośćprzedsiebiorstw pośrednictwa keredytowego..., 2007-2013]. 
W tabelach: 1.-7. zaprezentowano dane statystyczne obrazujące znaczenie rynku pośrednictwa kredytowego w Polsce w latach 2007-2013. W poszczególnych latach w badaniu odpowiednio uczestniczyła następująca liczba przedsiębiorstw: 2007 rok - 33 firmy; 2008 rok - 47 firm; 2009 rok - 56 firm; 2010 rok - 59 firm; 2011 rok 64 firmy; 2012 rok - 69 firm; 2013 rok - 118 firm.

Według danych statystycznych GUS, w 2007 roku na 33 przedsiębiorstwa zajmujące się pośrednictwem kredytowym aż 29 z nich udzielało kredytów pochodzących od banków, a zaledwie 4 firmy udzielały pożyczek z własnych środków. W okresie 2007-2012 stopniowo wśród badanych podmiotów rosła liczba przedsiębiorstw wykorzystujących własne środki w celu udzielania pożyczek. Natomiast w 2013 roku na 118 badanych podmiotów aż 50 z nich udzielało pożyczek z własnych środków (tabela 1.), [Driałalność..., 2007-2013]. Może to być sygnał do podjęcia znaczących decyzji w zakresie regulacji rynku pośrednictwa i doradztwa finansowego w kontekście stabilności systemu finansowego i ochrony konsumenta.

W firmach pośrednictwa kredytowego znajduje zatrudnienie coraz więcej osób. Jeszcze w 2007 roku badane podmioty zatrudniały około 7719 osób, a w 2013 roku już 16225 osób [Džiałalność..., 2007-2013], (tabela 2.).

TABELA 2.

Liczba zatrudnionych w przedsiębiorstwach pośrednictwa kredytowego w Polsce, w latach 2007-2013

\begin{tabular}{|c|c|c|c|c|c|c|c|}
\hline Rok & $\mathbf{2 0 0 7}$ & $\mathbf{2 0 0 8}$ & $\mathbf{2 0 0 9}$ & $\mathbf{2 0 1 0}$ & $\mathbf{2 0 1 1}$ & $\mathbf{2 0 1 2}$ & $\mathbf{2 0 1 3}$ \\
\hline $\begin{array}{l}\text { Liczba zatrudnionych } \\
\text { w firmach pośrednic- } \\
\text { twa kredytowego }\end{array}$ & 7719 & 7764 & 7930 & 7536 & 11074 & 11933 & 16225 \\
\hline
\end{tabular}

Źródło: dane GUS: [Driałalnośćpržedsiebiorstw pośrednictwa kredytowego..., 2007-2013].

Ponadto, według danych statystycznych GUS, przedsiębiorstwa pośrednictwa kredytowego rozbudowują sieć stacjonarnych własnych punktów sprzedaży oferowanych produktów, co świadczy o przyjęciu ekspansywnej strategii rozwoju działalności (w 2007 roku - 639 punktów sprzedaży, a w 2013 roku - 1169), (tabela 3.).

TABELA 3. Ilość stacjonarnych własnych punktów sprzedaży przedsiębiorstw pośrednictwa kredytowego w Polsce, w latach 2007-2013

\begin{tabular}{|c|c|c|c|c|c|c|c|}
\hline Rok & $\mathbf{2 0 0 7}$ & $\mathbf{2 0 0 8}$ & $\mathbf{2 0 0 9}$ & $\mathbf{2 0 1 0}$ & $\mathbf{2 0 1 1}$ & $\mathbf{2 0 1 2}$ & $\mathbf{2 0 1 3}$ \\
\hline $\begin{array}{l}\text { Ilość stacjonarnych } \\
\text { własnych punktów } \\
\text { sprzedaży }\end{array}$ & 639 & 760 & 692 & 741 & 946 & 1042 & 1169 \\
\hline
\end{tabular}

Źródło: dane GUS: [Driatalność pržedsiebiorstw pośrednictwa kredytonvego..., 2007-2013]. 
Z kolei, analizując dane dotyczące liczby umów na kredyty i pożyczki przedsiębiorstw pośrednictwa kredytowego (tabela 4.), warto zauważyć, że w 2007 roku ilość tych transakcji była na poziomie 4,9 mln, jednak w kolejnych latach zaczęła znacznie obniżać się, co szczególnie było widoczne w okresie ostatniego kryzysu finansowego. Dopiero w 2013 roku wolumen umów na kredyty i pożyczki przekroczył 3,2 mln, ale nadal nie osiagnął poziomu z 2007 roku.

TABELA 4.

Liczba umów na kredyty i pożyczki przedsiębiorstw pośrednictwa kredytowego w Polsce, w latach 2007-2013 roku

\begin{tabular}{|l|c|c|c|c|c|c|c|}
\hline \multicolumn{1}{|c|}{$\begin{array}{c}\text { Umowy na po- } \\
\text { szczególne rodzaje } \\
\text { kredytów }\end{array}$} & \multicolumn{7}{|c|}{ Liczba umów na kredyty i pożyczki } \\
\cline { 2 - 7 } & $\mathbf{2 0 0 7}$ & $\mathbf{2 0 0 8}$ & $\mathbf{2 0 0 9}$ & $\mathbf{2 0 1 0}$ & $\mathbf{2 0 1 1}$ & $\mathbf{2 0 1 2}$ & $\mathbf{2 0 1 3}$ \\
\hline $\begin{array}{l}\text { Umowy na kredyty } \\
\text { i pożyczki ogółem } \\
\text { (w mln) }\end{array}$ & 4,9 & 3,3 & 2,1 & 1,9 & 2,2 & 2,94 & 3,2 \\
$\begin{array}{l}\text { Umowy na kredyty } \\
\text { i pożyczki gotówkowe } \\
\text { i ratalne (w mln) } \\
\begin{array}{l}\text { Umowy na kredyty } \\
\text { hipoteczne (w tys.) }\end{array}\end{array}$ & 4,3 & 3,2 & 2,0 & 1,8 & 2,1 & 2,86 & 3,1 \\
$\begin{array}{l}\text { Umowy na kredyty sa- } \\
\text { mochodowe (w tys.) } \\
\begin{array}{l}\text { Umowy na kredyty } \\
\text { konsolidacyjne (w tys.) }\end{array}\end{array}$ & 17,3 & 18,4 & 1,8 & 3,2 & 14,3 & 4,6 & 9,7 \\
\hline
\end{tabular}

Źródło: dane GUS: [Działalność przedsiębiorstw pośrednictwa kredytowego..., 2007-2013].

W 2007 roku wartość udzielonych kredytów i pożyczek przez firmy pośrednictwa kredytowego wynosiła ponad $23157 \mathrm{mln}$ zł, potem uległa znacznemu obniżeniu, w 2010 roku osiąając najniższą w badanym okresie wartość $13421 \mathrm{mln}$ zł. Jednak w 2013 roku nastąpił istotny wzrost wartości kredytów i pożyczek przedsiębiorstw zajmujących się pośrednictwem kredytowym (44 $314 \mathrm{mln}$ zł) z czego aż 63\% to kredyty i pożyczki gotówkowe, ratalne i kartowe (tabela 5.). Zatem w omawianym okresie 2007-2013 w koszyku kredytów i pożyczek udzielanych przez te podmioty przeważały kredyty hipoteczne aż do 2013 roku, kiedy całkowicie zmieniła się ta tendencja. Ponadto oczekuje się dalszego wzrostu znaczenia pośrednictwa kredytowego w dystrybucji kredytów oraz rozwoju doradztwa finansowego na rynku. 
TABELA 5.

Wartość udzielonych kredytów i pożyczek przez przedsiębiorstwa pośrednictwa kredytowego w Polsce, w latach 2007-2013

\begin{tabular}{|c|c|}
\hline Rok & Wartość udzielonych kredytów i pożyczek \\
\hline 2007 & $\begin{array}{l}23 \text { 157,9 mln zł - ogółem (49\% ogółu stanowiła wartość kredytów hipotecznych) } \\
10487,6 \text { mln zł - kredyty, pożyczki gotówkowe i ratalne } \\
11379,7 \text { mln zł - kredyty hipoteczne, 509, } 1 \text { mln zł - kredyty samochodowe }\end{array}$ \\
\hline 2008 & $\begin{array}{l}24125 \mathrm{mln} \text { zł - ogółem (61\% ogółu stanowiła wartość kredytów hipotetycznych) } \\
8462,7 \mathrm{mln} \text { zł - kredyty, pożyczyczki gotówkowe i ratalne } \\
14736,8 \mathrm{mln} \text { zł - kredyty hipoteczne, 590, } 6 \mathrm{mln} \text { zł - kredyty samochodowe } \\
286,9 \mathrm{mln} \text { zł - kredyty konsolidacyjne }\end{array}$ \\
\hline 2009 & $\begin{array}{l}14 \text { 767,6 mln zł - ogółem (69,5\% ogółu stanowiła wartość kredytów hipotetycznych) } \\
4161,9 \mathrm{mln} \text { zł - kredyty, pożyczki gotówkowe i ratalne } \\
10 \text { 259,3 mln zł - kredyty hipotetyczne, } 41,1 \mathrm{mln} \text { zł - kredyty samochodowe } \\
196,9 \mathrm{mln} \text { zł - kredyty konsolidacyjne }\end{array}$ \\
\hline 2010 & $\begin{array}{l}13 \text { 421,5 mln zł - ogółem (84,3\% ogółu stanowiła wartość kredytów hipotetycznych) } \\
1760,9 \mathrm{mln} \text { zł - kredyty, pożyczki gotówkowe i ratalne } \\
11319,4 \mathrm{mln} \text { zł - kredyty hipoteczne, 106, } 5 \mathrm{mln} \text { zł - kredyty samochodowe } \\
148,3 \mathrm{mln} \text { zł - kredyty konsolidacyjne }\end{array}$ \\
\hline 2011 & $\begin{array}{l}20 \text { 480,8 mln zł - ogółem (72,5\% ogółu stanowiła wartość kredytów hipotetycznych) } \\
4775,6 \mathrm{mln} \text { zł - kredyty, pożyczki gotówkowe i ratalne } \\
14855 \mathrm{mln} \text { zł - kredyty hipoteczne, 369,5 mln zł - kredyty samochodowe } \\
174 \mathrm{mln} \text { zł - kredyty konsolidacyjne }\end{array}$ \\
\hline 2012 & $\begin{array}{l}18 \text { 074,4 mln zł - ogółem (60\% ogółu stanowiła wartość kredytów hipotetycznych) } \\
6539,3 \mathrm{mln} \text { zł - kredyty, pożyczki gotówkowe i ratalne } \\
10 \text { 807,9 mln zł - kredyty hipoteczne, 50,9 mln zł - kredyty samochodowe } \\
\text { 490,4 mln zł - kredyty konsolidacyjne }\end{array}$ \\
\hline 2013 & $\begin{array}{l}44 \text { 314,5 mln zł - ogółem (63\% ogółu stanowiła wartość kredytów i pożyczek gotów- } \\
\text { kowych ratalnych i kartowych) } \\
27964,6 \mathrm{mln} \text { zł - kredyty, pożyczki gotówkowe, ratalne i kartowe } \\
14 \text { 608,2 mln zł - kredyty hipoteczne, } 397 \text { mln zł - kredyty samochodowe } \\
525,7 \text { mln zł - kredyty konsolidacyjne }\end{array}$ \\
\hline
\end{tabular}

Źródło: dane GUS: [Driałalnośćpržedsiebiorstw pośrednictwa kredytowego..., 2007-2013].

Analizując dane GUS dotyczące monitoringu prowadzonego przez przedsiębiorstwa pośrednictwa kredytowego w latach 2007-2013 (tabela 6.), można zauważyć, że wraz ze zwiększaniem się liczby tych firm wzrasta ilość podmiotów, które przeprowadzają monitoring udzielonych kredytów i pożyczek (w 2007 roku - 11 firm, a w 2013 roku - 58 firm). Z kolei, w badanym okresie jest również zauważalna znaczna tendencja wzrostowa przedsiębiorstw prowadzących windykację zagrożonych należności (w 2007 roku - 7 firm, a w 2013 roku - 61 firm), co świadczy między innymi o słabszej kondycji finansowej dłużników, a tym samym wiąże się $\mathrm{z}$ większymi problemami ze ściaganiem należności przez te firmy [Driałalność..., 2007-2013]. 
TABELA 6.

Monitoring i windykacja udzielonych kredytów i pożyczek prowadzonych przez przedsiębiorstwa pośrednictwa kredytowego w Polsce, w latach 2007-2013

\begin{tabular}{|l|c|c|c|c|c|c|c|}
\hline Monitoring i windykacja udzie- & \multicolumn{7}{|c|}{ Ilość firm w poszczególnych latach } \\
\cline { 2 - 8 } \multicolumn{1}{|l}{ lonych kredytów i pożyczek } & $\mathbf{2 0 0 7}$ & $\mathbf{2 0 0 8}$ & $\mathbf{2 0 0 9}$ & $\mathbf{2 0 1 0}$ & $\mathbf{2 0 1 1}$ & $\mathbf{2 0 1 2}$ & $\mathbf{2 0 1 3}$ \\
\hline Firmy prowadzące monitoring & 11 & 21 & 29 & 28 & 29 & 39 & 58 \\
Podmioty prowadzące windykację & 7 & 11 & 11 & 20 & 14 & 34 & 61 \\
zagrożonych należności & & & & & & & \\
\hline
\end{tabular}

Źródło: dane GUS: [Driałalność pržedsiebiorstw pośrednictwa kredytowego..., 2007-2013].

TABELA 7.

Wartość wypłaconych kredytów hipotecznych (w mln zł) przez wybrane instytucje doradztwa finansowego i pośrednictwa kredytowego w Polsce, w latach 2007-2013

\begin{tabular}{|l|c|c|c|c|c|c|c|}
\hline \multirow{2}{*}{ Nazwa instytucji } & \multicolumn{6}{|c|}{ Wartość wypłaconych kredytów hipotecznych (w mln zł) } \\
\cline { 2 - 8 } & $\mathbf{2 0 0 7}$ & $\mathbf{2 0 0 8}$ & $\mathbf{2 0 0 9}$ & $\mathbf{2 0 1 0}$ & $\mathbf{2 0 1 1}$ & $\mathbf{2 0 1 2}$ & $\mathbf{2 0 1 3}$ \\
\hline Expander & 2864 & 3600 & 1591,8 & 2002 & 2470 & 1950 & 2948 \\
Open Finance + Home & $4700^{* *}$ & $5100^{* *}$ & $7019,9^{* *}$ & 7991 & 9097,9 & 6057 & 4853 \\
Broker & & & & & & & \\
Dom Kredytowy Notus & 1271 & 1630 & 1194,4 & 1982 & b.d. & 2016,1 & 2198,23 \\
Money Expert & 350 & 400 & 360,45 & 769 & $1164,2^{*}$ & - & - \\
Grupa AZ Finanse & 87 & 148 & 280,55 & 412 & $378,2^{*}$ & - & - \\
Doradcy 24 & 0 & 500 & 430 & 648 & 614,6 & 453,3 & 474,6 \\
Gold Finance & 0 & 253 & 234,7 & 293 & 430 & 586,8 & 701,34 \\
Credit House Polska D.K. & 0 & 194 & 151,69 & 209 & 178,3 & b.d. & b.d. \\
Real finance & 0 & 28 & 13,38 & 17 & 71 & b.d. & b.d. \\
Aspiro S.A. & - & - & - & 900 & 1532,4 & 1237,4 & 972,01 \\
\hline
\end{tabular}

* upadłość; ${ }^{* *}$ Open Finance

b.d. - brak danych

Źródło: opracowanie własne na podstawie danych ZFDF oraz stron internetowych wymienionych w tabeli doradców finansowych.

Z powyższych danych wynika, że skala działania podmiotów zajmujących się doradztwem finansowym i pośrednictwem kredytowym jest znaczna, co wyraża się chociażby w ilości oraz wartości udzielonych przez nie kredytów i pożyczek. Stąd ustawowe oraz nadzorcze regulowanie rynku doradztwa finansowego ma istotne znaczenie dla bezpieczeństwa klientów, a tym samym stabilności systemu finansowego. W związku z tym, istotna pozostaje kwestia zwiększenia zaufania wśród klientów do instytucji pośrednictwa kredytowego i doradztwa finansowego. 


\section{Podsumowanie}

Jak podaje K. Waliszewski, na rynku doradztwa finansowego występuje pewnego rodzaju nienadażanie regulacji prawnych za rozwojem tego rynku, ponieważ jedyne regulacje obowiązujące doradców finansowych to:

- przepisy dotyczące outsourcingu bankowego w Ustanie Prawo bankowe z 2004 roku;

- przepisy wprowadzające dyrektywę MiFID;

- Ustawa o kredycie konsumenckim z maja 2011 roku [Waliszewski, 2013, s. 633].

W ramach nowelizacji ustawy Prawo bankowe uregulowano m.in. zasady zlecania podmiotom trzecim wykonywania czynności zastrzeżonych dla banków tzw. outsourcing bankony [Ustawa, 2004]. Ponadto instytucje doradzające w zakresie produktów inwestycyjnych i ubezpieczeniowych są objęte nadzorem KNF w obszarze pośrednictwa ubezpieczeniowego i doradztwa finansowego poprzez dyrektywę MiFID [Waliszewski, 2010, s. 210]. Natomiast jednym z postanowień Ustawy o kredycie konsumenckim jest nałożony na pośredników finansowych obowiązek informowania klientów o tym, z jakimi kredytodawcami współpracują oraz czy otrzymują od nich wynagrodzenie [Ustawa, 2011, art. 7, 28]. Niebankowe instytucje finansowe (NBIF) mają coraz większy wpływ na stabilność sektora bankowego, a tym samym systemu finansowego i w związku z tym, że prowadzą coraz szerszą działalność finansową, ważna pozostaje kwestia regulacji tych instytucji. Mimo starań mających na celu utrzymanie równowagi na rynku finansowym i stabilności systemu finansowego, rynek doradztwa finansowego nadal wymaga wprowadzenia wielu regulacji.

Nowak, Rudnicki podaja, że koncepcja standaryzacji zawodu doradcy finansowego powinna opierać się na opracowaniu aktu prawnego, w którym zostałyby określone: warunki i zasady wykonywania doradztwa finansowego, organizacji samorządu doradców finansowych, jak również zasady ich funkcjonowania. Co więcej, warto byłoby wdrożyć model oceny kwalifikacji w obszarze doradztwa finansowego według ustalonych kryteriów oraz opracować standardy oceny kwalifikacji osób podejmujących działalność w ramach doradztwa finansowego [Nowak, Rudnicki, 2010, s. 237]. W porównaniu z rynkami doradztwa finansowego: amerykańskim, brytyjskim czy niemieckim, które należą do najlepiej rozwiniętych w tym obszarze, rynek doradców finansowych w Polsce wymaga wielu zmian, szczególnie w związku ze wzrostem znaczenia tego rynku, co potwierdza postawioną w artykule hipotezę badawcza, przede wszystkim wprowadzenia systemowego nadzoru zewnętrznego oraz licencjonowania pośredników i doradców finansowych. Warto przyjrzeć się rynkowi doradztwa finansowego chociażby w USA, gdzie rynek ten od 1997 roku podlega nadzorowi FSA (Financial Service Authority), a od 2013 roku FCA (Financial Conduct Authority). Na rynku tym doradcy mają obowiązek kwalifikacji na poziomie QCF 4, istnieje zakaz pobierania prowizji od instytucji finansowych, natomiast pomiędzy doradca a klientem musi być zachowana transparentność (pośrednik czy doradca,) [http://www.effp.pl]. Poza tym, nie należy zapominać, że implementacja regulacji rynku doradztwa finansowego może nie przebiegać w sposób bezproblemowy, głównie ze względu na niską świadomość korzyści z regulacji doradztwa i pośrednictwa finansowego dla konsumentów oraz systemu finansowego choć- 
by wśród polityków. Wśród barier rozwoju rynku doradztwa finansowego wymienia się: niski odsetek osób oszczędzających w Polsce i tym samym planujących swoje finanse osobiste, mierna świadomość ekonomiczną i finansowa społeczeństwa, a także niewielkie zaufanie do zawodu doradcy finansowego $z$ uwagi na brak jego regulacji i nadzoru państwowego oraz negatywnych doświadczeń klientów korzystających z usług doradców (np.: polisy oszczędnościowo-inwestycjne, mis-selling czy kredyty walutowe), [Waliszewski, Zięba, 2015].

\section{Literatura}

Bitz M. 1996 Produkty bankowe. Rynek ustug finansowych, tłumaczenie i opracowanie R. Kokoszczyński, Poltext, Warszawa.

Dokument elektroniczny, tryb dostępu: [http://jobs.euractiv.com/company/eurofinaseuropean-federation-finance-house-associations-10428, data wejścia: 11.06.2015].

Dokument elektroniczny, tryb dostępu: [http://stat.gov.pl/Klasyfikacje/doc/kzs/ pdf/KZiS_nowa.pdf, data wejścia: 17.06.2015].

Dokument elektroniczny, tryb dostępu: [http://www.bipar.eu/, data wejścia: 01.06.2015].

Dokument elektroniczny, tryb dostępu: [http://www.eafp.pl/, data wejścia: 01.06.2015].

Dokument elektroniczny, tryb dostępu: [http://www.effp.pl/, data wejścia: 27.09.2015].

Dokument elektroniczny, tryb dostępu: [http://www.effp.pl/page/2.html, data wejścia: 05.06.2015].

Dokument elektroniczny, tryb dostępu: [http://www.fecif.eu/, data wejścia: 05.06.2015].

Dokument elektroniczny, tryb dostępu: [http://www.posrednicy.org.pl/statut, data wejścia: 01.06.2015].

Dokument elektroniczny, tryb dostępu: [http://www.posrednicy.org.pl/kodeks-etyki, data wejścia: 01.06.2015].

Dokument elektroniczny, tryb dostępu: [https://www.kpf.pl/pliki/komentarz_eksperta/ odpowiedzialny_kredyt.pdf, data wejścia: 26.09.2015].

Dokument elektroniczny, tryb dostępu: [www.bgk.com.pl, data wejścia: 19.05.2015].

Dokument elektroniczny, tryb dostępu: [www.efpa-europe.org, data wejścia: 11.06.2015].

Dyrektywa 2004/39/WE Parlamentu Europejskiego i Rady z dnia 21 kwietnia 2004 roku w sprawie rynków instrumentów finansowych, Dz. U. UE L 114/60, 27.4.2006.

Driałalność przedsiębiorstw pośrednictwa kredytowego w 2007 r. - 2013 r., Raporty GUS za lata 2007-2013, Warszawa.

Iwanicz-Drozdowska M. 2009 Produkty finansowe $i$ edukacja finansowa w Polsce na tle wybranych krajón mysoko rozwinietych, Raport z badań 04/S/0010/08, SGH, Warszawa.

Janicka M. 2005 Jednolity rynek finansowy w Unii Europejskiej - poczatek kolejnego etapu „Zielona Ksiega”, „Bank i Kredyt”, nr 9.

Nowak J., Rudnicki M. 2010 Koncepcja regulacji kwalifikacji zawodowych doradców finansowych, [w:] System bankowy i rynki finansowe w warunkach globalnego kryzysu finansowego, K. Znaniecka, W. Gradoń (red.), Studia Ekonomiczne Uniwersytetu Ekonomicznego w Ka- 
towicach nr 71, Wydawnictwo Uniwersytetu Ekonomicznego w Katowicach, Katowice.

Rozporzadzenie Ministra Pracy i Polityki Społecznej w sprawie klasyfikacji zawodón i specjalności na potrzeby rynku pracy i polityki spotecznej oraz zakresu jej stosowania, z dnia 27 kwietnia 2010 roku (Dz.U. Nr 82, 2010, poz. 537. art. 36).

Rynek doradztwa finansowego w Polsce 2012, Raport Bankier.pl i „Wprost”, dokument elektroniczny, tryb dostępu: [http://www.bankier.pl/static/att/90000/2492942_ RaportRynekDoradztwaFinansowegowPolsce2012.pdf, data wejścia: 22.05.2015].

Sinkey J. F. C. 1998 Commercial Bank. Financial Management in the Financial - Services Industry, wyd. 5, Prentice Hall, New Jersey.

Uchwała nr 99/08 Komisji Nadzoru Finansowego z. dnia 18 czerwca 2008 roku w sprawie rekomendacii stosowania Kanonu Dobrych Praktyk. Rynku Finansowego, Dz. U. KNF, 2008, nr 3.

Ustawa o zmianie ustany - Prawo bankowe oraz zmianie innych ustaw z. 1 kwietnia 2004 roku (Dz. U. Nr 91, poz. 870).

Ustawa z. dnia 12 maja 2011 roku o kredycie konsumenckim (Dz.U. z 2011 roku, Nr 126, poz. 715 , art. 7 i 28 ).

Ustawa z. dnia 20 kwietnia 2004 roku art. 36 ust. 8 o promocji zatrudnienia $i$ instytucjach rynku pracy (Dz. U. 2004, Nr 99, poz. 1001).

Ustawa z. dnia 23 maja 1991 roku o organizacjach pracodawców (Dz.U. Nr 55, poz. 235 z późn. zm.).

Ustawa z. dnia 30 maja 1989 roku o iz̨ach gospodarczych (Dz.U. Nr 35, poz. 195 ze zm.). Uzasadnienie do Projektu Rozporzadzenia Listy Klasyfikacji i Standaryzacji Zawodów, „Uzasadnienie” nr $6 \mathrm{w}$ punkcie 3, dokument elektroniczny, tryb dostępu: [http://www.mpips.gov.pl/bip/download, data wejścia: 10.06.2015].

Waliszewski K. 2010 Nadzór i licencjonowanie doradón finansonych i pośredników kredytonych a stabilnośc i beapieczeństwo polskiego systemu bankowego, [w:] Banki i system bankony w obličn kryzysów finansonych, A. Janc (red.), Wydawnictwo Uniwersytetu Ekonomicznego w Poznaniu, Zeszyt Naukowy nr 155, Poznań.

Waliszewski K. 2012 Europejskie standardy doradztwa finansonvego w Polsce, [w:] Finanse w niestabilnym otoczeniu - Dylematy $i$ wyzwania, I. Pyka, J. Cichorska (red.), Studia Ekonomiczne. Zeszyty Naukowe Wydziałowe Uniwersytetu Ekonomicznego w Katowicach, Katowice.

Waliszewski K. 2013 Kanaty oddzialywania kryzysu finansowego na branż doradztwa finansowego w Polsce, Zarządzanie i Finanse, Uniwersytet Gdański, Gdańsk.

Waliszewski K. 2014 Planowanie finansów osobistych (zarzadzanie finansami osobistymi) ₹. udziatem doradców finansowych - znaczenie dla gospodarstw domowych i gospodarki, „Problemy Zarządzania", vol. 12, nr 4 (48), t. 1, Wspótczesne wyzwania w bankowości i finansach.

Waliszewski K., Zięba F. 2015 Polski rynek doradztwa finansowego na tle najwiekssych rynków europejskich, „Gazeta Finansowa”, 26 maja, dokument elektroniczny, tryb dostępu: [http://gf24.pl/polski-rynek-doradztwa-finansowego-na-tle-najwiekszychrynkow-europejskich/, data wejścia: 27.09.2015]. 